\title{
Economy of Jordan: obstacles and prospects of progress of a developing economy
}

\author{
Nouran Ali Afeef \\ Hamdan, graduate student, Peoples' Friendship University \\ of Russia (RUDN), \\ 108814, Moscow, Bachurinskaya Str \\ noun.bas@mail.ru
}

\author{
E.V. Savenkova \\ Doctor of Economics, Associate Professor, Professor, \\ Peoples' Friendship University of Russia (RUDN), \\ 117198, Moscow, Miklukho-Maklaya Str.,6 \\ savenkova_ev@rudn.university
}

\author{
Alexandr Y. Bystryakov \\ Peoples' Friendship University of Russia (RUDN) \\ 117198, Moscow, Miklukho-Maklaya \\ bystryakov_aya@rudn.university
}

\begin{abstract}
The article examines the economy of Jordan in general, the main problems of the economy in the developing country and ways to overcome them. The author summarized the most critical problems this economy faces such as budget deficit, high taxes and unemployment which lead to slower development of the economy and investment activities, included the possible directions of solving the problem of budget deficit and ways to attract investments in the country.
\end{abstract}

Keywords: developing economy; budget deficit; trade balance deficit; foreign aids; unemployment; taxes; corruption; total expenditures; public revenues; investment environment; investment attractiveness.

\section{INTRODUCTION}

It is generally accepted that the economies of small developing countries suffer from certain obstacles arising from the combination of many factors related to the size of these countries. These countries have a number of structural problems: the small size of the population and, consequently, the small size of their markets, their limited resources and vulnerability to natural disasters, their dependence on the export of small amounts of raw materials or local products in foreign currency.

\section{MAJOR PROBLEMS OF THE ECONOMY OF JORDAN}

The Hashemite Kingdom of Jordan is one of the developing countries with an open economy that is vulnerable to macro and micro influences.

The main problems of the economy of Jordan include:

Jordan is not an industrial country - it depends on service sector and tourism. Industry produces $30 \%$ of the economy of Jordan, but manufacturers suffer from high costs, especially the energy prices, which make $35 \%$ of the costs and the weak financing from banks, aside from that, industry faces a number of problems, in particular, weakness of the local market and competition from imported products.

Jordan is one of the largest exporters of phosphates and potassium fertilizers in the world, including in the pharmaceutical, phosphate and potash industries. Nevertheless, according to the analysis of the data from the Central Bank, imports exceed exports (Table 1.):

TABLE I. JORDAN'S EXPORTS AND IMPORTS FOR THE PERIOD (2000-
\begin{tabular}{|l|l|l|}
\hline Year & $\begin{array}{l}\text { Exports } \\
\text { (Jordanian dinar) }\end{array}$ & $\begin{array}{l}\text { Imports } \\
\text { (Jordanian } \\
\text { dinar) }\end{array}$ \\
\hline 2000 & 1.080 .817 .000 & 3.259 .404 .000 \\
\hline 2001 & 1.352 .370 .000 & 3.453 .729 .000 \\
\hline 2002 & 1.556 .748 .000 & 3.599 .160 .000 \\
\hline 2003 & 1.675 .075 .000 & 4.072 .008 .000 \\
\hline 2004 & 2.306 .626 .000 & 5.799 .241 .000 \\
\hline 2005 & 2.570 .222 .000 & 7.442 .864 .000 \\
\hline 2006 & 2.929 .310 .000 & 8.187 .725 .000 \\
\hline 2007 & 3.183 .707 .000 & 9.722 .194 .000 \\
\hline 2008 & 4.431 .113 .000 & 12.060 .895 .000 \\
\hline 2009 & 3.579 .166 .000 & 10.107 .696 .000 \\
\hline 2010 & 4.216 .948 .000 & 11.050 .126 .000 \\
\hline 2011 & 4.805 .873 .000 & 13.440 .215 .000 \\
\hline 2012 & 4.749 .570 .000 & 14.733 .749 .000 \\
\hline 2013 & 4.805 .234 .000 & 15.667 .344 .000 \\
\hline 2014 & 5.163 .029 .000 & 16.280 .189 .000 \\
\hline 2015 & 4.797 .583 .000 & 14.537 .181 .000 \\
\hline 2016 & 5.331 .400 .000 & 13.637000 .000 \\
\hline & & Source: Central bank of Jordan [1]
\end{tabular}

Tourism is one of the most important sectors of Jordan's economy and makes up to $13 \%$ of GDP "Gross Domestic Product", however, the profitability of this sector decreases, according to the Ministry of Tourism of Jordan, the number of tourists in 2015 was 5326501 tourists, and in 2016 $1,127,236$. Profits declined in the years indicated from $3,106,600$ to 624,000 dinars, which is explained by higher 
prices for flights and accommodation in hotels, as well as an unstable geopolitical situation in neighboring countries [2].

- High level of the government's budget deficit: this reflects the increase in the level of total expenditures over the public revenues; it is the gap between the public revenues and total expenditures summed as a percentage of GDP "Gross Domestic Product".

Based on the data of the Central Bank of Jordan, a table of public revenues, total expenditures and the gap between them was created (table 2):

TABLE II. PUBLIC REVENUES AND TOTAL EXPENDITURES FOR THE PERIOD OF (2006-2017)

\begin{tabular}{|l|l|l|l|}
\hline Year & $\begin{array}{l}\text { Total } \\
\text { expenditures } \\
\text { (Jordanian } \\
\text { dinar) }\end{array}$ & $\begin{array}{l}\text { Public revenues } \\
\text { (Jordanian dinar) }\end{array}$ & $\begin{array}{l}\text { Gap between } \\
\text { them (Jordanian } \\
\text { dinar) }\end{array}$ \\
\hline $\mathbf{2 0 0 6}$ & 3.912 .300 .000 & 3.468 .800 .000 & -443.500 .000 \\
\hline $\mathbf{2 0 0 7}$ & 4.586 .000 .000 & 3.971 .000 .000 & -615.000 .000 \\
\hline $\mathbf{2 0 0 8}$ & 5.431 .000 .000 & 4.783 .300 .000 & -692.700 .000 \\
\hline $\mathbf{2 0 0 9}$ & 5.975 .900 .000 & 4.526 .200 .000 & -1.449 .700 .000 \\
\hline $\mathbf{2 0 1 0}$ & 5.708 .000 .000 & 4.662 .800 .000 & -1.054 .200 .000 \\
\hline $\mathbf{2 0 1 1}$ & 6.796 .600 .000 & 5.415 .800 .000 & -1.380 .800 .000 \\
\hline $\mathbf{2 0 1 2}$ & 6.878 .100 .000 & 5.054 .500 .000 & -1.823 .600 .000 \\
\hline $\mathbf{2 0 1 3}$ & 7.065 .400 .000 & 5.758 .200 .000 & -1.307 .200 .000 \\
\hline $\mathbf{2 0 1 4}$ & 7.851 .100 .000 & 7.276 .600 .000 & -583.500 .000 \\
\hline $\mathbf{2 0 1 5}$ & 7.722 .900 .000 & 6.796 .300 .000 & -926.600 .000 \\
\hline $\mathbf{2 0 1 6}$ & 7.948 .200 .000 & 7.069 .500 .000 & -878.700 .000 \\
\hline $\mathbf{2 0 1 7}$ & 8.173 .300 .000 & 7.425 .400 .000 & -747.900 .000 \\
\hline
\end{tabular}

Source: Central bank of Jordan [3]

- Increasing public debt - in order to finance the budget deficit and other vital projects in energy and water supply, the total public debt gradually increased over the years and reached $86.2 \%$ of the GDP. The table below shows the increasing both public and domestic debts for the period of (2013-2016):

TABLE III. NET PUBLIC DEBT AND NET DOMESTIC DEBT FOR THE PERIOD OF (2013-2016):

\begin{tabular}{|l|l|l|l|l|}
\hline Year & $\mathbf{2 0 1 3}$ & $\mathbf{2 0 1 4}$ & $\mathbf{2 0 1 5}$ & $\mathbf{2 0 1 6}$ \\
\hline $\begin{array}{l}\text { Net public Debt } \\
\text { (JD million) }\end{array}$ & $19,096.8$ & $20,555.5$ & $22,847.9$ & $24,079.4$ \\
\hline $\begin{array}{l}\text { Net Domestic } \\
\text { Debt (JD } \\
\text { million) }\end{array}$ & $11,862.2$ & $12,525.4$ & $13,457.4$ & $13,780.4$ \\
\hline
\end{tabular}

Source: Ministry of Finance [4]
The high level of unemployment persists for many years, which has a negative impact on the economic development of the country and slows it down. According to the Ministry of Labor of Jordan the unemployment rate reached $18.5 \%$ in 2017 which, in turn, reflects a low level of economic development, the lack of opportunities to create new jobs with an average income level.

According to the statistics unemployment rate among men reached $16.1 \%$ while among women $27.5 \%$ and by education the rate of unemployed people with higher education reached $22.8 \%[5]$.

Another unemployment problem appeared with the arrival of Syrian refugees, which made a cheap labor and competition to the local labor, although the government promised to create about new 200000 work opportunities for refugees; it is still another obstacle to fight unemployment high rates.

The constant increase in taxes, especially indirect taxes, on vital goods of basic consumption and services, including water, electricity, fuel, medicine, cars and other goods, has led to a decrease in the real income level of the population. According to the Central Bank data, there is an increase in taxes if in 2016 taxes were collected for a total of 4.597.000.000 Jordanian dinars, in 2017 this amount increased to 5.201 million dinars. Table 3. shows the amount of taxes for the period (2010-2017)

TABLE IV. THE AMOUNT OF TAXES FOR THE PERIOD (2010-2017):

\begin{tabular}{|l|l|}
\hline Year & Taxes (Jordanian dinar) \\
\hline $\mathbf{2 0 1 0}$ & 2.986 .300 .000 \\
\hline $\mathbf{2 0 1 1}$ & 3.062 .200 .000 \\
\hline $\mathbf{2 0 1 2}$ & 3.351 .400 .000 \\
\hline $\mathbf{2 0 1 3}$ & 3.652 .400 .000 \\
\hline $\mathbf{2 0 1 4}$ & 4.073 .100 .000 \\
\hline $\mathbf{2 0 1 5}$ & 4.096 .300 .000 \\
\hline $\mathbf{2 0 1 6}$ & 4.597 .000 .000 \\
\hline $\mathbf{2 0 1 7}$ & 5.201 .000 .000 \\
\hline
\end{tabular}

Source: General budget department of Jordan [6]

This decision of the Jordanian government to impose new taxes on many goods and products, justified as a way to reduce the public debt of about 35 billion dollars.

In a response to these decisions to increase the prices of a number of goods and services and higher taxes, demonstration went viral in many cities.

Problems with corruption, Jordan, according to the International Organization for Combating Corruption and the study of corruption (Transparency international), in 2016 ranked 57 in the world with estimate of 48 while in 2017 it moved to 59 rank with a score of 48 too. (The index ranks countries by their perceived levels of public sector corruption, uses a scale of 0 to 100 , where 0 is highly corrupt and 100 is very clean.) The aspects of corruption can range from abuse of using authority, waste and financial loss of public money to fraud and money laundering.

The average aftermath of corruption yearly ranges between 1,250,000 and 6000000 US dollars [7].

Dependence of foreign aids: 
The Jordanian economy relies on foreign aids, both Arabic and Western, which comes in grants, soft loan or technical assistance.

1) Grants received by the Kingdom can be classified as follows:

Grants to support the public budget through the Ministry of Planning and International Cooperation. These grants are provided as direct support to the State Treasury to finance the projects and development programs contained in the government's budget plan, or be held as additional allocations within the government's budget for the ministries budgets that will finance specific projects agreed with the donor.The main donors that provide budget support grants include the United States of America, the European Union and Japan, Germany, Canada, Italy, Spain, France China, South Korea, United Nations organizations, the World Bank, the European Investment Bank, the International Fund for Agricultural Development, the OPEC Fund for International Development, the Arab Fund for Economic and Social Development, the Islamic Development Bank, the Kuwait Fund for Arab Economic Development and the Abu Dhabi Development Fund

Grants administered directly by countries, donors and international bodies. These grants finance vital development programs and projects. The management of these programs and projects funded through this type of the grant is carried out under the financial and administrative regulations of the donors, in close coordination with government institutions and subject to the control of the Audit Bureau and the relevant national regulatory bodies.

2) Soft loans aim to provide funding for a number of major priority development programs and projects in the infrastructure, water and sanitation, energy, education, health and other sectors, as well as supporting the public budget. Such loans are characterized by easy financing terms, low interest rates ranging between $0 \%-4 \%$ and the repayment period of 15-40 years, including the grace period of 5-9 years.

The volume of foreign aid is provided to the Kingdom during the period of (2006-2015)

The amount of foreign aid (grants and soft loans) committed by various countries, donors and funds, whose agreements were signed during the period of (2004-2015) reached about 16 billion dollars, where the value of grants provided during that period is 10.8 billion dollars. The value of soft loans contracts reached (5.2) billion dollars to support developmental projects in critical sectors in addition to supporting the government's budget.

The value of foreign aid provided to Jordan (grants, soft loans and additional grants within the Jordanian response plan) from various countries, donors and funds reached a total of about (3.15) billion dollars. In this case, the value of committed grants is a total of about 1.930 .434 billion dollars, including a total of 600.6 million dollars in grants to support refugees within the Jordanian response plan for the Syrian crisis, while soft loans contracted by a total of 0.923 billion dollars. Fig. 1 shows the relative distribution of foreign aids for 2016 coming from Arabic and western countries and funds.

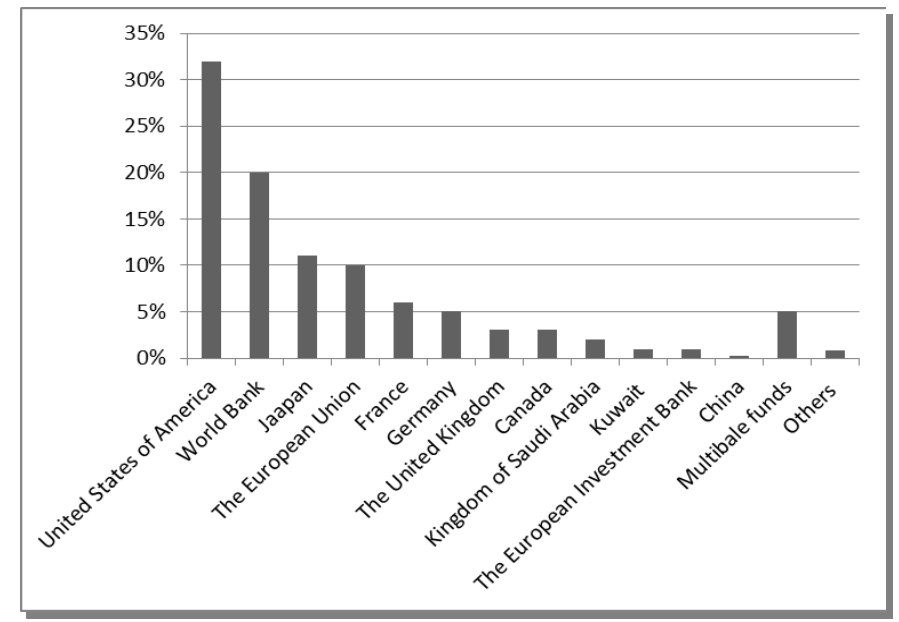

Source: the Jordanian Ministry of Planning and International Cooperation/ the figure made by the author depending on the data of Ministry of Planning and International cooperation Jordan for 2016 [8]

Fig.1 Relative distribution of foreign aid for 2016 (without refugee grants):

In 2017, it decreased by $45.7 \%$, reaching about 234 million dollars for the first 9 months of that year. Decline in aid and grants size (especially from GCC countries), on which the Jordanian economy depends, is dramatic.

According to statistics published by the Jordanian Ministry of Planning published on its website, the volume of Saudi aid decreased from 474.3 million dollars in 2015 to 165 million dollars only in 2017. Experts explain this decline in aids, especially from Arabic countries, as a response to a certain Jordanian political position on different regional issues as a sort of pressure to do otherwise.

This vast decline in aids has deepened the pressure on the Jordanian economy.

The high cost of sheltering Syrian refugees in Jordan: the Syrian crisis had added strain on the country's economy and infrastructure and put pressure on all sectors including education, health, housing, water and electricity supply. According to official estimates, the number of Syrian refugees living in the Kingdom is estimated as 1.3 million refugees. The cost of housing refugees in Jordan is estimated in the period from 2011 to 2017 and is 6700000000 US dollars, while the estimated cost of the Jordanian response plan for the Syrian crisis for many years (2018-2020) is about 7,312 billion US dollars to provide assessment in education, health, food security, shelters and livelihoods, social protection and local governance and municipal affairs.

While some sectors may have benefited from the population increase of 1.3 million refugees, which is about $20 \%$ of the population, the overall impact of the Syrian crisis on the Jordanian economy is detrimental [9].

\section{RECOMMENDATIONS FOR THE DEVELOPMENT OF THE ECONOMY OF JORDAN}

In order to achieve stable economic development in Jordan, it is necessary to overcome the above-mentioned problems, first of all, budget deficit and unemployment. 
World experience after the crisis of 2008 shows that the reduction in the budget deficit is possible by either cutting expenditures or raising taxes. Some economists argue that the best way to restore recover the fiscal sector is to cut expenditures. Others, on the contrary, insist that expenditures cutting is not constructive, as it is detrimental to economic growth. They prescribe an even greater increase in public spending to revive the sluggish economy.

In the new study of Finance and Development, it is assumed that short-term expenditure reduction policies have proven to be more effective than raising taxes showing the experience of developed countries, while austerity policies can have different effects on developing countries that can lead to unsatisfying results [10].

In the case of Jordan, there are two groups of experts with different view about the priorities of the economy, the first group of economists support increasing total expenditures to achieve a rapid growth in economy even if that will lead to higher budget deficit, while the other group of economists demand to solve the budget deficit problem regardless of the economic growth.

The first point of view is that increasing government's expenditures will lead to economic activity and growth and will attract foreign investments, which will increase the public revenues through taxes, and so it will decrease the budget deficit. While cutting total expenditures will slow investments movements, which will lead to declining economic growth and as a result higher levels of poverty and unemployment.

The second group of economists says that increasing government's expenditures without control on budget deficit will cause critical economic problems such as increasing the public debt which makes about $80 \%$ of GDP, in order the need for more financing will appear and this means more foreign financial aids and credits. Their view is that increasing government's expenditures will not necessarily lead to economic growth as there are many factors that influent on it, such as on which projects will be spent and how much these projects will add to the economic growth, geopolitical influences such as oil prices and decline in tourism movements.

A healthy economic growth will promote enhancing economic relationships with Arabic and foreign countries in order to attract cash flows in the country and finding job opportunities for Jordanian labor abroad, also to activate trading among these countries to increase exports, especially with Arabic countries like Libya, Egypt, Tunisia.

It is necessary to reduce the budget deficit by taking new measures, including:

Applying economic policies that aim to expand sources of income reduces expenditures and inflation. The main sources of income of the country are money transfers of citizens abroad (mainly working in neighboring countries of the Persian Gulf), foreign financial aids from developed countries and international organizations and taxes. However, the unstable economic situation in these countries (dependent on oil prices) makes these incomes volatile, also the greater dependence on taxes as a source of income has led to higher production costs and the lack of interest of investors in investing their money in this country, so it is necessary to create new sources of income including:

- $\quad$ Finding new markets for its products - generally the main markets of Jordanian exports are the neighboring countries of the Persian Gulf and Iraq, as they are unstable and their ongoing changing legislative regulations that can hinder a stable trade with these countries, such as the new customs restrictions led by Iraq against some of the Jordanian products. It is necessary to find new markets with different levels of development to obtain a various customer base.

- Improve production in accordance with international standards; also encourage new industries in the country.

- It is essential to promote the tourism industry by providing a better infrastructure for building new accommodations, organizing festivals and events to attract tourists, regulation of the prices and costs of traveling and residence.

- Increasing the investment attractiveness of the country. For this, it is necessary to simplify the procedures for issuing documents and to offer manufacturers tax incentives; provide the infrastructure necessary for business (road construction, provision of water, sanitation and electricity, social projects for health and education); apply anti-corruption measures.

It is also essential to reduce the deficit of trade balance, which is always in minus as imports in US dollars always overgrow exports in US dollars. That forces the government to use federal reserve in the central bank of Jordan to finance this deficit or by domestic or foreign credits, which in its turn increases the public debt that is already makes up to $86.2 \%$ of GDP.

By analyzing the data Department of Statistics of Jordan, over the period of (2013-2016), the trade balance kept a deficit, but with a relative decline in 2013 its value was $8,270.1$, and in 2014 it increased to $-8,495.6$, while in 2015 it decreased to 7,336.2 and in $2016-6,761.5$.

Advert to other problems of Jordanian economy, dependence on foreign aids as main source of revenues make it difficult to have independence from a political and economic point of view. In the foreseeable future, it might seem impossible to totally get rid of this dependence on foreign aids, but it is necessary to take steps towards a total economic independence. This requires gradual substitution of these resources by promoting investments in effective economic projects; creating new vacancies to reduce unemployment and a better use of the available human resources.

The constant increase in taxes, especially indirect taxes, on vital goods of basic consumption and services, including water, electricity, fuel, medicine, cars and other goods, has led to a decrease in the real income level of the population.

In a response to these decisions to increase the prices of a number of goods and services and higher taxes, demonstration went viral in many cities. Inflation high rates led the 
government to take further austerity measures aimed at what is called "rationalization of consumption and control of the financial situation." These measures included reducing the expenses of government departments and raise taxes and fuel prices in a manner that will lead to the expansion of poverty in the country, according to almost all observers. This led to demonstrations called for the government to be overthrown and rejected what protesters called "policies of impoverishment and collection." The government's austerity steps are part of its commitments to a structural and financial reform program required by the International Monetary Fund for Jordan. This shows how taxes put huge pressure on the economy, it is necessary to lead a moderate tax policy considering the capacity of public earnings.

In a geopolitical context, the experiences of the past two decades have shown the vital importance of the Iraqi and Syrian markets to Jordan even in the midst of political crises. Iraq supplied Jordan with cheap oil, while the Iraqi market absorbed Jordan's surpluses of food, light industry and household goods. The Syrian market was supplying the Jordanian market with clothing and food at attractive prices. This has helped ease pressure on the Jordanian budget, especially with regard to the oil derivatives bill and reducing the trade deficit. Hence the importance of re-opening trade channels and relations between the three countries after a break for years, especially as political situation indicate the possibility of doing so. On the other hand, Jordan is one of the countries that have diverse human competencies, especially in information technology and software. If the government provides support to small and medium-sized enterprises and embraces them to stand on their feet, Jordan can become a center for the development of this software for its market and other Arab and foreign markets.

\section{CONCLUSION}

Developing countries are an important component of the world economy. They have a large amount of labor and raw materials, which make them attractive for foreign investments, but the undeveloped infrastructure and inadequate tax legislation create threats to any business.

Investments made in developing countries lead to enhancing economic growth and development of the economy. According to the United Nations, foreign direct investments (FDI) flows to developing countries in 2013 topped that of developed countries. While businesses entering the developing countries' markets face vast challenges, many companies already successfully operate in these markets such as carmakers, banks, telecompanies and supermarkets [11].

Jordan as a developing country has a number of obstacles that slow its economy, including: budget deficit, low production, dependence on foreign aids, high taxes, unemployment, corruption and geopolitical influences in the form of an unstable situation in neighboring countries and the issue of Syrian refugees.

To overcome these obstacles, the government needs to get rid of typical solutions in the form of increasing taxes to increase revenues and create new directions for the development of the economy and increase the investment attractiveness of the country by applying economic policies that aim to expand sources of income. It is necessary to reduce expenditures and inflation, such as: finding new markets for its products, improve production in accordance with international standards; also encourage new industries in the country, promote the tourism industry, increasing the investment attractiveness of the country, and in a long term prospect, to gradually scale down dependence on foreign aids.

Despite of all these obstacles that face the Jordanian economy, it is fair to say that in other aspects Jordan is still having a political stability and security in spite of the geopolitical tension in neighboring countries, and a relatively economic stability represented by the fixed exchange rate of the national currency (Jordanian dinar) to the US dollar. Nevertheless the continuing budget deficit and trade balance deficit may strain the federal reserves in the central bank of Jordan and as a result the national currency will face a decrease in exchange rates against other currencies.

\section{References}

[1] Central bank of Jordan, different issues (2000-2016), http://statisticaldb.cbj.gov.jo/index?action=level4

[2] Ministry of tourism of Jordan (different statistics), http://www.mota.gov.jo/Contents/Tourism_Statistical_Newsletter_2016 Ar.aspx

http://www.mota.gov.jo/Contents/Tourism_Statistical_Newsletter__201Ar.aspx

[3] Central bank of Jordan, different issues(2006-2017), http://statisticaldb.cbj.gov.jo/index?action=level4

[4] Ministry of Finance Jordan (different issues) (2013-2016) www.mof.gov.jo

[5] R. Ali "Unemployment in Jordansettle at 18.5 percent in the last quarter of 2017”, “Anadolu agency”, Febreury 2018, 18.5 البطالة في الأردن نستقر عند

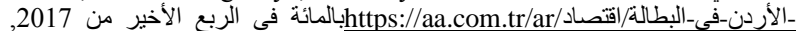

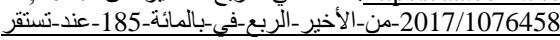

[6] General budget department of Jordan, different issues (2010-2017) www.gbd.gov.jo/en

[7] International, Transparency, «corruption Perception Index 2016», http://www.transparency.org/news/feature/corruption_perceptions_index _2016

[8] Ministry of Planning and International Cooperation, http://www.mop.gov.jo/Default.aspx

[9] Jordan response plan for the Syria crisis 2018-2020, http://www.jrpsc.org/

[10] A. Alesina, C.A. Favero, F. Giavazzi "Climbing Out of Debt", "Finance and development" journal, vol. 55,pp. 6-11, March 2018. www.imf.org/external/russian/pubs/ft/fandd/2018/03/index.htm

[11] S. Kuhn "A developing story", "Tax insights for business leaders", journal, vol.13, Focus Developing economies, 2015.

[12] M. Hasauna "Economy of Jordan: obstacles and threats","AlJAZEERA centre for studies,2017. مالك الخصاونة, "الاقتصاد الأردني: اختلالات و تحديات مركز م الجزيرة http://studies.aljazeera.net/ar/profile/170209131902876.html 